\title{
Analisis Faktor-faktor yang Mempengaruhi Pengembangan Kawasan Pariwisata Bahari di Gili Labak, Kabupaten Sumenep
}

\author{
Dwi Indah N dan Cahyono Susetyo \\ Jurusan Perencanaan Wilayah dan Kota, Fakultas Teknik Sipil dan Perencanaan, \\ Institut Teknologi Sepuluh Nopember (ITS) \\ Jl. Arief Rahman Hakim, Surabaya 60111 Indonesia \\ e-mail: csusetyo@gmail.com
}

\begin{abstract}
Abstrak-Gili Labak merupakan salah satu pulau kecil di Kabupaten Sumenep yang memiliki potensi pariwisata bahari. Namun potensi yang dimilki oleh Gili Labak tersebut belum disertai dengan adanya fasilitas yang memadai dan pengembangan yang juga belum maksimal. Tahapan pertama dalam penelitian ini adalah untuk menentukan potensi objek daya tarik wisata dengan skoring menggunakan skala Likert. Kemudian untuk mengetahui prioritas faktor-faktor pengembangan pariwisata bahari menggunakan analisis AHP. Hasil dari analisis menunjukkan bahwa di Gili Labak terdapat 4 objek daya tarik wisata yang sangat berpotensi untuk dikembangkan. Dan hasil analisis AHP menunjukkan bahwa prioritas faktor-faktor pengembangan adalah sarana dan prasarana, kemudian aksesibilitas, dan objek daya tarik wisata.
\end{abstract}

Kata Kunci-faktor-faktor, Pariwisata bahari, pengembangan, potensi.

\section{PENDAHULUAN}

$\mathrm{G}$ ILI Labak adalah adalah pulau dengan pantai pasir putih alami di sekeliling pulau yang cocok untuk menikmati pantai dan laut. Panorama terumbu karang dan ikan hias sebagai taman laut ini menjadi daya tarik tersendiri untuk melakukan kegiatan snorkeling dan diving [1]. Selain itu dalam Rencana Tata Ruang Wilayah (RTRW) Kabupaten Sumenep tahun 2009-2029, juga disebutkan bahwa Wilayah perairan laut Pulau Gili Labak di Kecamatan Talango ditetapkan sebagai taman wisata laut dan penyelamatan lingkungan hidup [2]. Tutupan terumbu karang yang terdapat di perairan Gili Labak adalah 39,80\% sampai 55\% dan tergolong dalam kategori sedang sampai baik. Terumbu karang yang dalam kondisi baik demikian menjadi habitat bagi 15 spesies ikan di perairan Gili Labak dan menjadi daya tarik wisata dengan melakukan kegiatan snorkeling. Diantara spesies ikan karang tersebut, terdapat ikan Napoleon Wrasse [3]. Di sisi lain kelemahan yang terdapat di Gili Labak ialah komponen pariwisata berupa sarana transportasi yang belum memiliki rute khusus dari Pelabuhan Kalianget serta untuk akomodasi pariwisata masih sangat terbatas, yaitu mengandalkan rumahrumah dari penduduk setempat sebagai penginapan.

Produk industri wisata sendiri adalah semua jasa yang dibutuhkan wisatawan semenjak ia berangkat sampai kembali lagi ke rumah dimana ia tinggal. Produk wisata sendiri terdiri dari berbagai unsur dan merupakan suatu package yang tidak terpisahkan, yaitu: Tourist object atau objek pariwisata yang terdapat pada daerah-daerah tujuan wisata, yang menjadi daya tarik orang -orang untuk datang berkunjung ke daerah tersebut; fasilitas yang diperlukan di tempat tujuan tersebut, seperti akomodasi perhotelan, bar dan restoran, entertainment dan rekreasi; ransportasi yang menghubungkan negara/daerah asal wisatawan serta transportasi di tempat tujuan ke objek objek pariwisata [5].

Oleh karena itu perlu diketahui potensi objek daya tarik wisata serta faktor-faktor yang dapat mempengaruhi pengembangan Gili Labak sebagai kawasan pariwisata bahari.

\section{METODE PENELITIAN}

\section{A. Metode Analisis}

Analisis dalam penelitian ini dilakukan dalam 2 tahap. Yang pertama adalah untuk melakukan identifikasi objek daya tarik wisata yang ada di Gili Labak. Yang kedua adalah untuk menentukan faktor-faktor yang menjadi prioritas dalam pengembangan kawasan pariwisata bahari di Gili Labak.

Pada tahap analisis identifikasi objek daya tarik wisata bahari di Gili Labak adalah dengan skoring menggunakan Skala Likert. Analisis skoring ini berdasarkan pendapat dari para stakeholders yang telah ditetapkan sebelumnya untuk menjadi responden. Data input yang digunakan adalah data kualitatif yang dikonversikan ke dalam skala likert. Kemudian dihitung jumlah dari masing-masing skor atau nilai dari objek daya tarik wisata di Gili Labak. Dari nilai bobot yang paling tinggi untuk masing-masing karakteristik objek daya tarik wisata di Gili Labak tersebut dapat diketahui objek daya tarik wisata yang berpotensi untuk dikembangkan.

Sedangkan untuk menentukan faktor-faktor yang menjadi prioritas pengembangan kawasan pariwisata bahari di Gili Labak digunakan analisis AHP atau Analitycal Hierarchy Process adalah model pendukung keputusan yang dikembangkan oleh Thomas L. Saaty. Hirarki didefinisikan sebagai suatu representasi dari sebuah permasaahan yang kompleks dalam suatu struktur multi-level, level pertama merupakan tujuan, keumudian level faktor, kriteria, subkriteria, dan seterusnya [6]. 


\section{ANALISA DAN PEMBAHASAN}

\section{A. Identifikasi Potensi Objek Daya Tarik Wisata Bahari di Gili Labak}

Dalam analisis objek daya tarik wisata yang berpotensi untuk dikembangkan sebagai pariwisata bahari di Gili Labak, dilakukan dengan menggunakan skala likert yang didasarkan pada penilaian dari stakeholder. Objek daya tarik wisata yang digunakan dalam masukan analisis ini berdasarkan studi literatur dan keadaan fisik yang terlihat, yaitu snorkeling, divng, surfing, berenang, dan menikmati pantai.

Tabel 1

Penilaian Objek Daya Tarik Wisata Yang Berpotensi Untuk Dikembangkan Sebagai Pariwisata Bahari Terhadap Variabel Diving

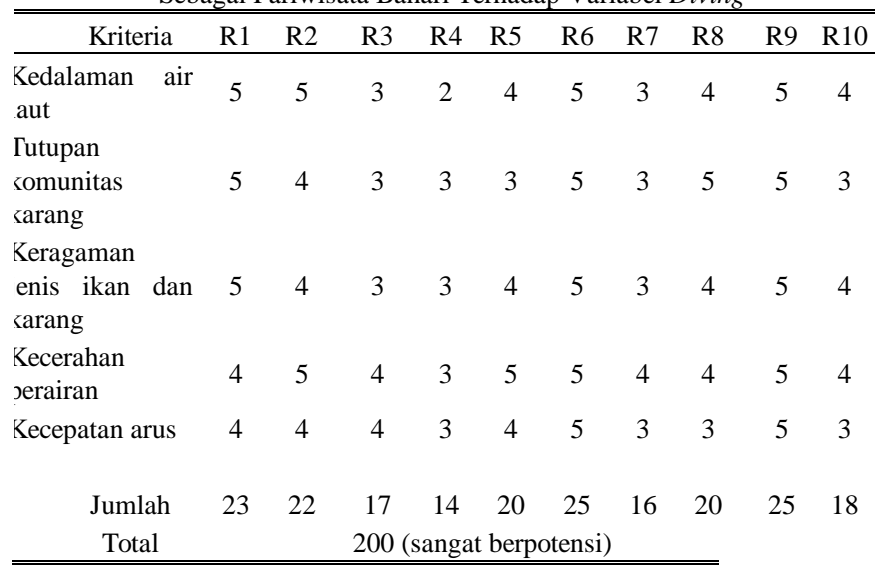

Tabel 2

Penilaian Objek Daya Tarik Wisata Yang Berpotensi Untuk Dikembangkan Sebagai Pariwisata Bahari Terhadap Variabel Snorkeling

\begin{tabular}{lcccccccccc}
\hline \multicolumn{1}{c}{ Kriteria } & R1 & R2 & R3 & R4 & R5 & R6 & R7 & R8 & R9 & R10 \\
\hline $\begin{array}{l}\text { Kedalaman air } \\
\text { aut }\end{array}$ & 4 & 5 & 3 & 3 & 5 & 5 & 3 & 4 & 5 & 4 \\
$\begin{array}{l}\text { Tutupan } \\
\text { रomunitas }\end{array}$ & 5 & 4 & 3 & 3 & 5 & 5 & 3 & 4 & 5 & 5 \\
रarang \\
$\begin{array}{l}\text { Keragaman jenis } \\
\text { kan dan karang }\end{array}$ & 5 & 4 & 3 & 3 & 4 & 5 & 3 & 5 & 5 & 3 \\
$\begin{array}{l}\text { Kecerahan } \\
\text { Jerairan }\end{array}$ & 5 & 5 & 4 & 3 & 5 & 5 & 5 & 3 & 5 & 4 \\
$\begin{array}{l}\text { Kecepatan arus } \\
\quad \text { Jumlah }\end{array}$ & 3 & 4 & 4 & 3 & 5 & 5 & 3 & 4 & 5 & 3 \\
$\quad$ Total & 22 & 17 & 15 & 24 & 25 & 17 & 20 & 25 & 19 \\
\hline \hline
\end{tabular}

Tabel 3

Penilaian Objek Daya Tarik Wisata Yang Berpotensi Untuk Dikembangkan Sebagai Pariwisata Bahari Terhadap Variabel Berenang

\begin{tabular}{|c|c|c|c|c|c|c|c|c|c|c|}
\hline Kriteria & $\mathrm{R} 1$ & $\mathrm{R} 2$ & R3 & R4 & R5 & R6 & R7 & $\mathrm{R} 8$ & R9 & $\mathrm{R} 10$ \\
\hline $\begin{array}{l}\text { Tinggi } \\
\text { Jelombang }\end{array}$ & 1 & 2 & 3 & 3 & 1 & 5 & 1 & 1 & 1 & 2 \\
\hline $\begin{array}{l}\text { Kecepatan } \\
\text { Angin }\end{array}$ & 1 & 2 & 4 & 3 & 1 & 5 & 1 & 1 & 1 & 1 \\
\hline Jumlah & 2 & 4 & 7 & 3 & 2 & 10 & 2 & 2 & 2 & 3 \\
\hline Total & \multicolumn{10}{|c|}{40 (kurang berpotensi) } \\
\hline
\end{tabular}

Tabel 4

Penilaian Objek Daya Tarik Wisata Yang Berpotensi Untuk Dikembangkan Sebagai Pariwisata Bahari Terhadap Variabel Surfing

\begin{tabular}{lcccccccccc}
\hline \hline \multicolumn{1}{c}{ Kriteria } & R1 & R2 & R3 & R4 & R5 & R6 & R7 & R8 & R9 & R10 \\
\hline $\begin{array}{l}\text { Kecepatan } \\
\begin{array}{l}\text { Arus } \\
\text { Kedalaman }\end{array}\end{array}$ & 4 & 4 & 4 & 3 & 5 & 5 & 5 & 5 & 5 & 4 \\
-aut & 4 & 3 & 3 & 5 & 5 & 5 & 3 & 5 & 4 \\
$\quad \begin{array}{c}\text { Jumlah } \\
\quad 7\end{array}$ & 84 & 7 & 3 & 10 & 10 & 10 & 8 & 10 & 8 \\
\hline \hline
\end{tabular}

Tabel 5

Penilaian Objek Daya Tarik Wisata Yang Berpotensi Untuk Dikembangkan Sebagai Pariwisata Bahari Terhadap Variabel Menikmati Pantai

\begin{tabular}{|c|c|c|c|c|c|c|c|c|c|c|}
\hline Kriteria & $\mathrm{R} 1$ & $\mathrm{R} 2$ & R3 & $\mathrm{R} 4$ & R5 & R6 & R7 & $\mathrm{R} 8$ & R9 & $\mathrm{R} 10$ \\
\hline $\begin{array}{l}\text { Kondisi } \\
\text { Isik } \\
\text { Jantai }\end{array}$ & 5 & 5 & 5 & 4 & 5 & 5 & 5 & 5 & 5 & 5 \\
\hline $\begin{array}{l}\text { cuas } \\
\text { santai }\end{array}$ & 4 & 5 & 5 & 4 & 5 & 5 & 5 & 3 & 5 & 5 \\
\hline Jumlah & 9 & 10 & 10 & 8 & 10 & 10 & 10 & 8 & 10 & 10 \\
\hline Total & \multicolumn{10}{|c|}{75 (sangat berpotensi) } \\
\hline
\end{tabular}

Keterangan:

R1: Wisatawan

R2: Tour Guide (Travel Orginizer)

R3: Expert Traveller

R4: Bappeda Sumenep / Kepala Bidang Sosial Budaya

R5: Kasi Pengelola Data Kesenian, Pemasaran, Kesenian dan

Wisata. Dinas Pariwisata dan Kebudayaan Kabupaten

Sumenep.

R6: Kepala Bidang Kelautan, Pesisir, dan Pulau-Pulau Kecil,

Dinas Kelautan dan Perairan Kabupaten Sumenep.

R7: Wisatawan

R8: Penyedia Perahu

R9: Ketua Kelompok Sadar Wisata Gili Labak

R10: Kabid Sarana dan Prasarana Wisata, Dinas Pariwisata dan Kebudayaan Kabupaten Sumenep.

Tabel 6

Kategori Potensi Objek Daya Tarik Wisata di Gili Labak

\begin{tabular}{cc}
\hline \hline Sangat Berpotensi & $\begin{array}{l}\text { Kurang } \\
\text { Berpoten }\end{array}$ \\
\hline 1. Diving & \\
2. Snorkeling & \\
3. Berenang & Surfing \\
4. Menikmati & \\
pantai & \\
\hline
\end{tabular}

\section{B. Prioritas Faktor-faktor yang Mempengaruhi}

Pengembangan Kawasan Pariwisata Bahari di Gili Labak

Penyusunan prioritas faktor ini menggunakan analisis AHP (Analytical Hierarchy Process). Dalam analisis AHP dilakukan dua tahap perbandingan. Yang pertama membandingkan antar kriteria kemudian antar sub-kriteria. Perbandingan kriteria oleh stakeholders terkait. Perbandingan kriteria tersebut diolah menjadi matriks perbandingan berpasangan (comparison pairwise) dengan menggunakan Expert Choice. Melalui pengolahan menggunakan aplikasi tersebut akan diketahui prioritas faktor pengembangan wisata bahari di Gili Labak. 


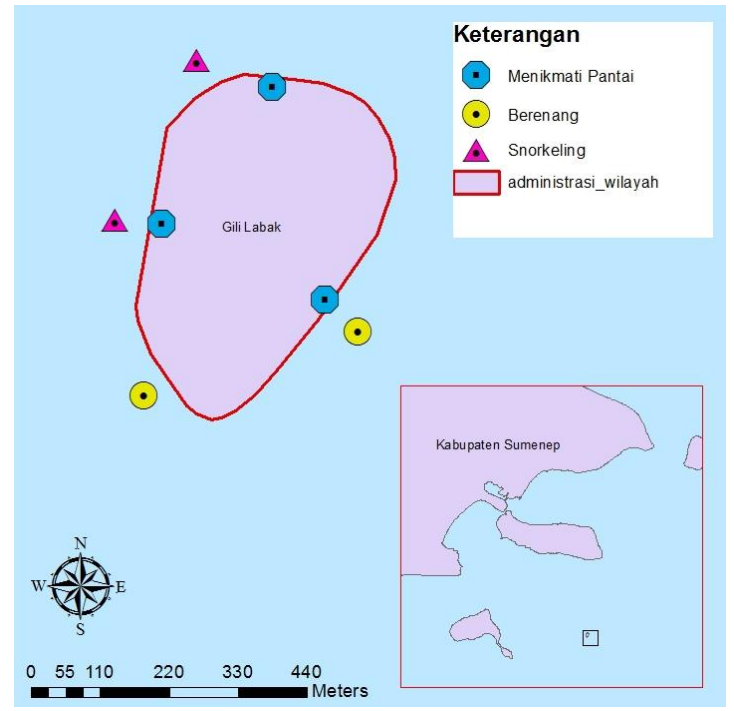

Gambar. 1. Peta Objek Daya Tarik Wisata di Gili Labak

Dari hasil analisis AHP didapatkan faktor sarana dan prasarana memperoleh tingkat prioritas tertinggi daripada Objek Daya Tarik Wisata dan juga aksesibilitas, yaitu sebesar 50,3\%. Kemudian yang mendapat tingkat prioritas kedua adalah aksesibilitas sebesar $28,7 \%$ dan yang ke-tiga adalah ODTW sebesar $21 \%$. Hal ini berarti dalam pengembangan pariwisata bahari di Gili Labak, faktor yang menjadi prioritas yang dikembangkan adalah sarana dan prasarana yang mendukung kegiatan wisatawan selama melakukan wisata di Gili Labak.

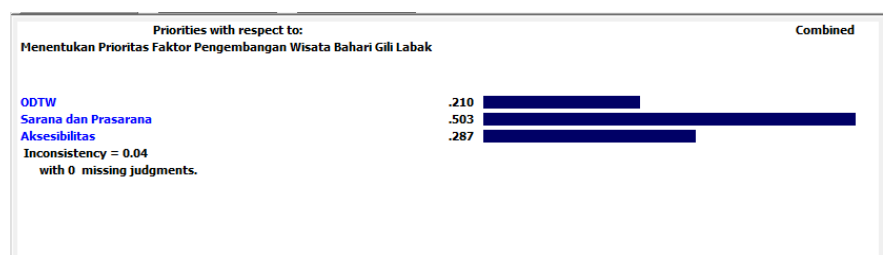

Gambar. 2. Prioritas Faktor Pengembangan Pariwisata Bahari di Gili Labak a Objek Daya Tarik Wisata di Gili Labak

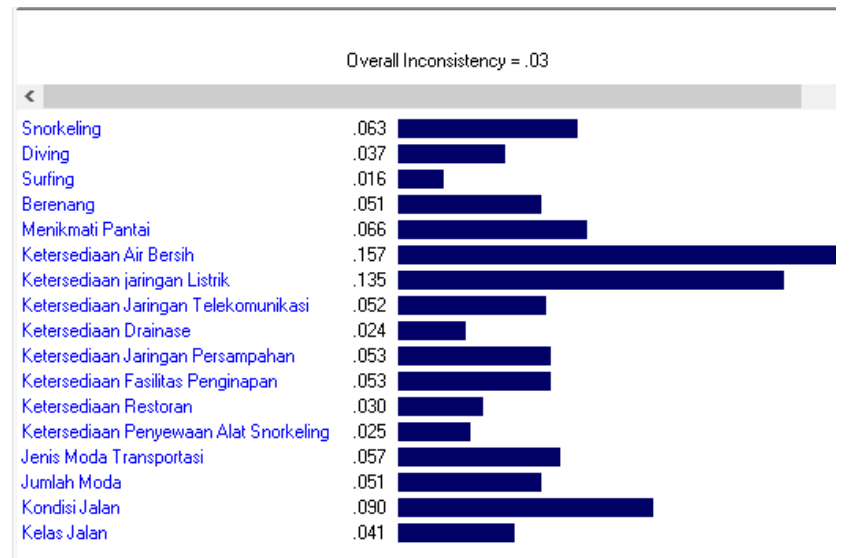

Gambar. 3. Bobot Kriteria Penentuan Prioritas Faktor Pengembangan

Pariwisata Bahari di Gili Labak

\section{KESIMPULAN}

Berdasarkan hasil analisis dan pembahasan yang telah dilakukan sebelumnya, jenis kegiatan wisata yang berpotensi untuk dikembangkan di Gili Labak ada dua, yaitu kegiatan wisata aktif dan pasif. Kegiatan wisata aktif yang sangat berpotensi untuk dikembangkan adalah snorkeling, diving, dan berenang. Sedangkan kegiatan wisata pasif yang sangat berpotensi untuk dikembangkan adalah rekreasi menikmati pantai.

Prioritas faktor pengembangan wisata bahari di Gili Labak berdasarkan hasil analisis AHP adalah sebagai berikut:

1. Sarana dan Prasarana dengan urutan sebagai berikut:

- Ketersediaan air bersih

- Ketersediaan jaringan listrik

- Ketersediaan fasilitas penginapan

- Ketersediaan jaringan persampahan

- Ketersediaan jaringan telekomunikasi

- Ketersediaan restoran

- Ketersediaan penyewaan alat snorkeling

- Ketersediaan drainase

2. Aksesibilitas dengan urutan sebagai berikut:

- Kondisi jalan

- Jenis moda transportasi

- Jumlah moda

- Kelas jalan

3. Objek Daya Tarik Wisata dengan urutan sebagai berikut:

- Menikmati pantai

- Snorkeling

- Berenang

- Diving

- Surfing

\section{DAFTAR PUSTAKA}

[1] Anonim. 2013. Yuk ke Gili Labak.Diunduh Tanggal 31 Oktober 2013 dari http://www.griyawisata.com/nasional/madura-island/artikel/yuk-ke-pulaugilik-lebak

[2] Rencana Tata Ruang Wilayah Kabupaten Sumenep, 2009

[3] Panggabean, Anthony Sisco, Mardlijah, Siti. Pralampita, An Wiwiet. Terumbu Karang Buatan Sebagai Inovasi Pengkayaan Stok Napoleon Wrasse di Perairan Pantai Gili Labak. Balai Riset Perikanan Laut. Badan Riset Kelautan dan Perikanan. Dewan Riset - Kementrian Ristek. Jakarta. 2010.361

[4] A, Yoeti, Oka. PengantarIlmuPariwisata. Angkasa. Bandung. 1996.

[5] Dahuri, Rokhimin. Rais, Jacub. Dan Ginting, Putra Sapta. Sitepu, M.J. Pengelolaan Suber Daya Wilayah Pesisir dan Lautan Secara Terpad,. Pradya, Paramita Jakarta. 2004.

[6] McIntosh, Robert W. and Shashikant Gupta. Tourism, Principles, Practices, Philosophies. Grid Publishing Inc.: Ohio. 1980

[7] Hall CM. Trends in ocean and coastal tourism: the end of the last frontier? Ocean \& Coastal Management, 44 : 601-618. 2001. 